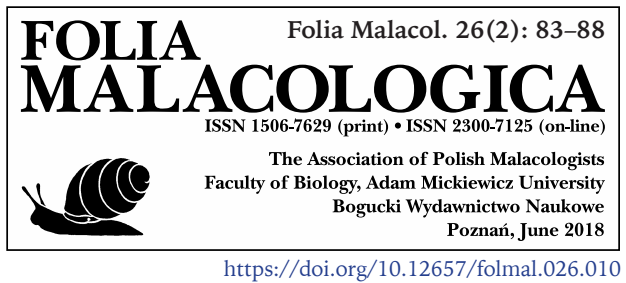

\title{
A NEW SPECIES OF GROSSUANA (CAENOGASTROPODA: TRUNCATELLOIDEA: HYDROBIIDAE)
}

\author{
HANS D. BOeters ${ }^{1 *}$, Peter GlÖER², ANDRZEJ FALNiOWSKI ${ }^{3}$ \\ ${ }^{1}$ Karneidstr. 8, D 81545 München, Germany (e-mail: boeters@t-online.de) \\ 2Biodiversity Research Laboratory, Schulstr. 3, D 25491 Hetlingen, Germany (e-mail: gloeer@malaco.de) \\ ${ }^{3}$ Department of Malacology, Institute of Zoology, Jagiellonian University, Ingardena 6, 30-060 Kraków, \\ Poland (e-mail: andrzej.falniowski@uj.edu.pl) \\ *corresponding author
}

ABSTRACT: Paludina hohenackeri Küster, 1853 from Greece is a junior synonym of Radomaniola tritonum (Bourguignat, 1852) [Hydrobia]; Grossuana hohenackeri sensu auctorum is described as a new species.

KEY WORDS: Radomaniola tritonum, Paludina hohenackeri, Grossuana tembii, new species, species identification, Greece

\section{INTRODUCTION}

FALNIOWSKI et al. (2012) studied genetically Hydrobia tritonum Bourguignat, 1852 and Paludina hohenackeri Küster, 1853 sensu auctorum, both from Greece. They found that H. tritonum belonged to the genus Radomaniola Szarowska, 2006. However, they assigned $P$. hohenackeri to Grossuana Radoman, 1973 (FALNIOWSKI et al. 2012: 25, fig. 3 G19, 32, 33, fig. 14 G19, 2016: 308, table 1). The type locality of $P$. hohenackeri given by KÜSTER (1853) was "in Griechenland". Syntypes of $P$. hohenackeri are unknown. Consequently, BOETERS et al. (2017) inves-

\section{MATERIAL AND METHODS}

Whorls were counted according to GITTENBERGER et al. (1970). Anatomical examination followed BOETERS (1999). Shells, animals and their parts were drawn with LEICA M80 Drawing Mirror. Shell length and diameter were measured with a $5 \mathrm{~mm}$ measure plate $(0.05 \mathrm{~mm}$ grading) at $40 \times$ magnification; measurements were rounded to the nearest $0.05 \mathrm{~mm}$. Photographs of shells were taken with a LEICA R8 digital system. tigated the material in CHARPENTIER's (1855) collection which was the basis of Küster's description. As regards the Radomaniola/Grossuana group sensu FALNIOWSKI et al. (2012) in Greece, BOETERS et al. (2017) compared shells from a total of 56 localities scattered over Greece with shells of the original material in Charpentier's collection. Only a sample from a spring in Kefalari at Lerna, the type locality of H. tritonum, corresponded to Paludina hohenackeri in Charpentier's collection. Thus, the understanding of Küster's Paludina hohenackeri needs revision.

The following material was examined:

(1) Radomaniola tritonum: (I) BOURG - 1 shell ["phot. Richling"], 14 shells, and 2 shells glued on cardboard; label "Bythinella tritonum Bourgt", partially covering older label: "types Marais de Lerna (Grèce)."; (II) CHARP [CHARPENTIER 1855: 20, "Tritonum Bourg. Arcadis ... d'exampl. ... 100"; 6 shells thereof seen on photographs provided by Musée Cantonal de Zoologie à Lausanne]; (III) CHARP - neotype of 
Paludina hohenackeri +30 shells +1 juv. shell incrusted in aperture. Label no. 1 with green sticker "94": "Pal. Hohenackeri Charp. Küst. Tab. 13 f. 18-19. Hohenacre Grèce 1848"; label no. 2: "208 [in red] Hohenackeri Charp. Paludina brevis ["brevis" crossed out] Hohenaceri Graecia 1848"; label no. 3 stuck on box: "Hohenackeri Charp."; (IV) REI and (V) BOE 3377 - Greece, Peloponnese, spring in Kefalari at Lerna, P. et A. REISCHÜTZ leg. VIII. 2008.

(2) Grossuana tembii n. sp.: Greece, Athena, Thembi

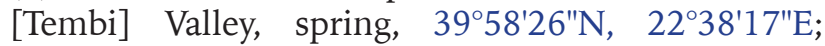

FALNIOWSKI leg., (I) SMNS/holotype; (II) BOE 3418/ paratypes.

ABBREVIATIONS: BOE - Collection Boeters (München); BOURG - Collection Bourguignat, Museum d'Histoire Naturelle (Genève); CHARP Collection Charpentier, Musée Cantonal de Zoologie (Lausanne); GLÖER - Collection Glöer (Hetlingen); REI - Collection P. et A. Reischütz (Horn); SMNS Staatliches Museum für Naturkunde (Stuttgart); d shell diameter; $\mathrm{h}$ - shell height; $\mathrm{h} / \mathrm{d}$ - shell height/ diameter ratio

\section{RESULTS}

\section{Radomaniola tritonum (Bourguignat, 1852)}

Hydrobia tritonum, BOURGUIGNAT 1852: 24.

Type locality: "Graeciam, in aquis paludosis lacus Lernae, habitat." ["Ce Mollusque habite sous les feuilles des plantes aquatiques des eaux fangeuses du marais de Lerne, en Grèce." (BOURGUIGNAT 1853: 64)].

Bithinia [sic] tritonum, BOURGUIGNAT 1853: 64, pl. 2, figs 29-31.

Paludina hohenackeri, KÜSTER 1853: 77, pl. 13, figs 18-19.

Type locality: "in Griechenland".
Radomaniola tritonum, FALNIOWSKI et al. 2012: 24, fig. 2 G5, 29, fig. 7 G5, 33, fig. 14 G5.

?Radomaniola tritonum, BOETERS et al. 2017: 194.

Shell (Figs 1-5). Syntypes: Figs 4-5, topotypes see FALNIOWSKI et al. (2012: 22 plus 24, fig. 2 G5); SCHÜTT 1980: pl. 9, fig. 6 is doubtful). For measurements see Table 1.

Operculum: chestnut-coloured.

Table 1. Shell measurements of Radomaniola tritonum and Grossuana tembii n. sp.

\begin{tabular}{|c|c|c|c|c|}
\hline Species & Height $(\mathrm{h})[\mathrm{mm}]$ & Diameter (d) [mm] & $\mathrm{h}: \mathrm{d}$ & Collection \\
\hline \multicolumn{5}{|c|}{ Radomaniola tritonum (Bourguignat, 1852) } \\
\hline & 1.700 & 1.125 & 1.51 & \multirow{2}{*}{ BOURG } \\
\hline & 1.675 & 1.150 & 1.46 & \\
\hline & 1.680 & 1.100 & 1.53 & \multirow{5}{*}{$\begin{array}{c}\text { CHARP (neotype } P \text {. hohenackeri) } \\
\text { BOE } 3377\end{array}$} \\
\hline & 1.725 & 1.150 & 1.50 & \\
\hline & 1.675 & 1.150 & 1.46 & \\
\hline$(\mathrm{n}=5)$ mean & 1.690 & 1.135 & 1.49 & \\
\hline $\min -\max$ & $1.67-1.72$ & $1.12-1.15$ & $1.46-1.53$ & \\
\hline \multicolumn{5}{|c|}{ Grossuana tembii n. sp. } \\
\hline & 1.750 & 1.200 & 1.46 & \multirow[t]{15}{*}{ BOE 3418} \\
\hline & 1.950 & 1.275 & 1.53 & \\
\hline & 1.925 & 1.250 & 1.54 & \\
\hline & 1.850 & 1.300 & 1.42 & \\
\hline & 1.750 & 1.250 & 1.40 & \\
\hline & 1.750 & 1.200 & 1.46 & \\
\hline & 1.750 & 1.200 & 1.46 & \\
\hline & 1.775 & 1.250 & 1.42 & \\
\hline & 1.775 & 1.225 & 1.45 & \\
\hline & 1.850 & 1.350 & 1.37 & \\
\hline & 1.850 & 1.225 & 1.51 & \\
\hline & 1.750 & 1.325 & 1.32 & \\
\hline & 2.000 & 1.325 & 1.51 & \\
\hline$(\mathrm{n}=13)$ mean & 1.83 & 1.26 & 1.45 & \\
\hline $\min -\max$ & $1.75-2.00$ & $1.20-1.35$ & $1.32-1.54$ & \\
\hline
\end{tabular}

$\mathrm{n}$ - number of shells 


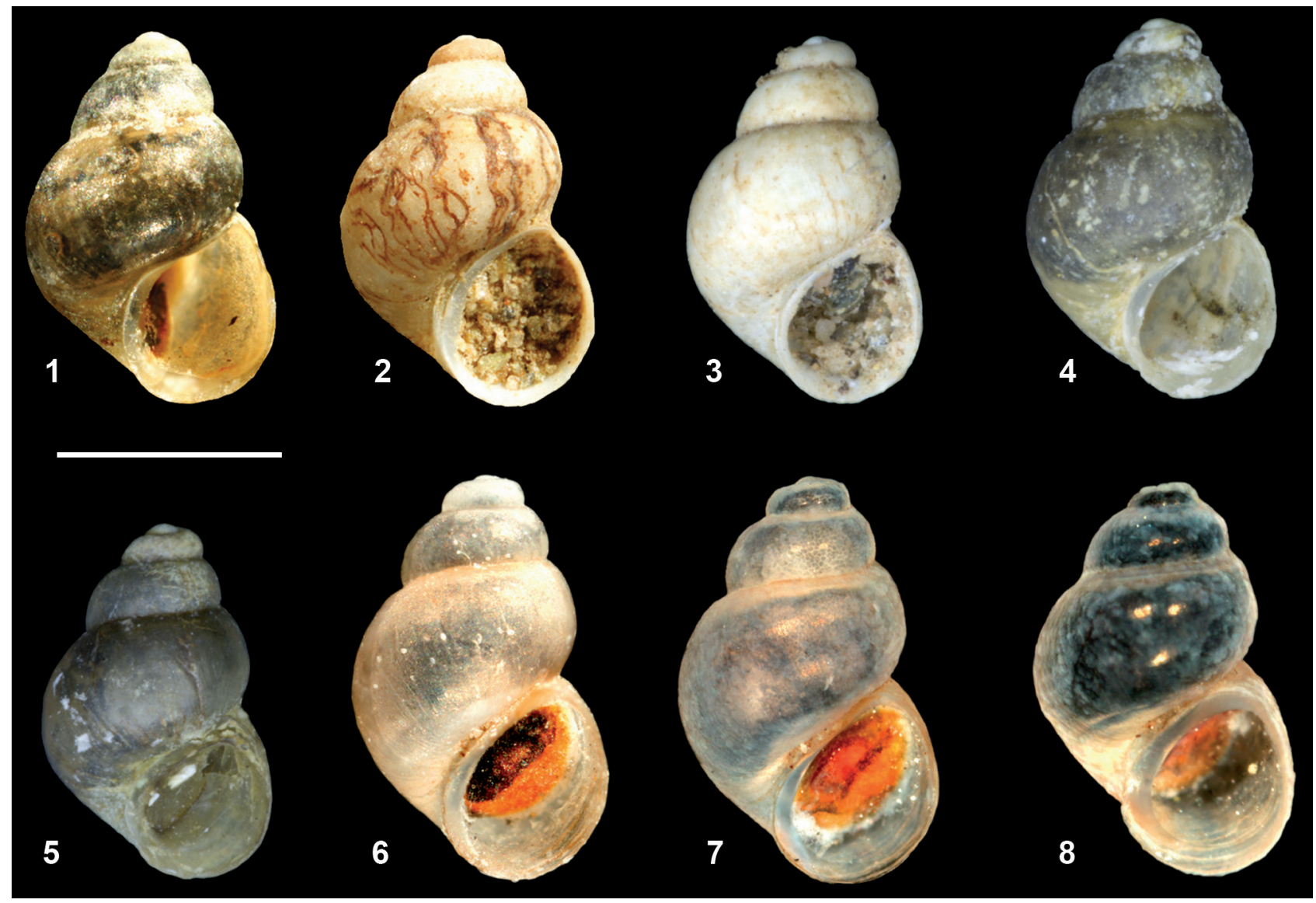

Figs 1-8. Radomaniola tritonum (Bourguignat, 1852): 1 - neotype of Paludina hohenackeri Küster, 1853, "in Griechenland" (CHARP); 2-3 - Greece, Peloponnese, spring in Kefalari at Lerna (BOE 3377 ex REI); 4-5 - syntypes of Hydrobia tritonum Bourguignat, 1852, "Graeciam, in aquis paludosis lacus Lernae" (BOURG). 6-8 - Grossuana tembii n. sp., Greece, Athena, Thembi [Tembi] valley: 6-7 - holotype (SMNS, FALNIOWSKI leg., 6 - photographed dry, 7 - in ethanol); 8 paratype (BOE 3418, FALNIOWSKI leg. et don.)

Anatomy: Penis lobe bifurcated (FALNIOWSKI et al. 2012: 29, fig. 7 G5). Female genitalia not yet described.

Molecular data: FALNIOWSKI et al. (2012: 33, fig. 14 G5).

Habitat and distribution: Known from the type locality and its neighbourhood only: a spring at

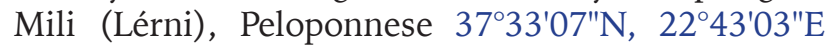
(FALNIOWSKI et al. 2012: 22, table 1) and a spring in Kefalari at Lerna (REI; BOE 3377).

Remarks: BOETERS et al. (2017) showed that the shells from the spring in Kefalari at Lerna, the type locality of $H$. tritonum, corresponded to the material in Charpentier's collection, used in 1853 for the description by KÜSTER (1853) and finally for the designation of the neotype of Paludina hohenackeri Küster, 1853 by BOETERS et al. (2017).

We compared the neotype of Paludina hohenackeri Küster, 1853 with the syntypes of $H$. tritonum Bourguignat, 1852; they turned out to be conspecific.

\section{Grossuana tembii n. sp.}

Grossuana hohenackeri, FALNIOWSKI et al. 2012: 25, fig. 3 G19, 30, fig. 8 G19, 33, fig. 14 G19.

Type locality: spring of Athena, Thembi [Tembi] Valley $39^{\circ} 58^{\prime} 26^{\prime \prime} \mathrm{N}, 22^{\circ} 38^{\prime} 17^{\prime \prime} \mathrm{E}$ (FALNIOWSKI et al. 2012: 22 table 1).

Etymology: The species' name refers to the type locality, the Thembi [Tembi] valley.

Shell (Figs 6-8): Ovoid, transparent and smooth, conical, of 3.25 to 3.5 whorls with straight sidelines and moderately pronounced suture, neither ascending nor descending on shell wall; parietal border of aperture fused with shell wall; parietal and columellar border strongly thickened; palatal and basal border of aperture neither broadened nor thickened; maturity reflected by a closely spaced series of growth stripes; columellar border slightly broadened, closing umbilicus or leaving it slit-like open. 

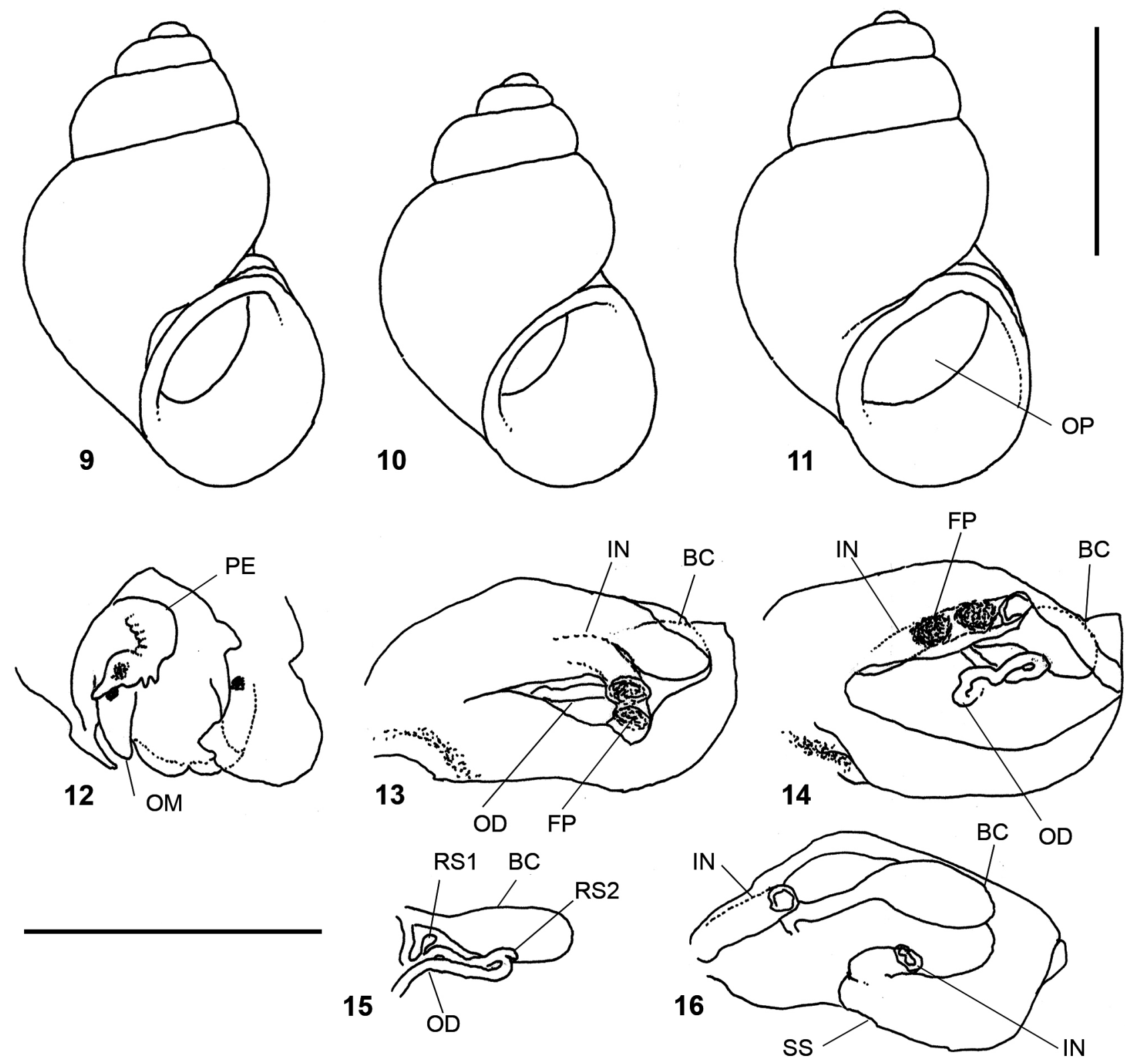

Figs 9-16. Grossuana tembii n. sp. Greece, Spring of Athena, Thembi [Tembi] valley, paratypes (BOE 3418, FALNIOWSKI leg. et don.): 9-11 - shells (9 - male; 10-11 - females); 12-16 - soft parts: 12 - male, head with penis exposed through slit in mantle, same specimen as 9; 13-16 -females (13-15 - renal cavity stepwise opened, and renal oviduct plus bursa copulatrix, RS1 and RS2 isolated, same specimen as 11; 16 - bursa copulatrix exposed though opening of renal cavity, same specimen as 10). Scale bars - $1 \mathrm{~mm}$. Abbreviations: BC - bursa copulatrix, FP - faecal pellet, IN - intestine, OD - renal oviduct, OM - ommatophore, OP - operculum, PE - penis, RS1 - distal receptaculum, RS2 - proximal receptaculum, $\mathrm{SS}$ - style sac

Measurements: $\mathrm{h}-1.75-2.00 \mathrm{~mm}$, mean $1.83 \mathrm{~mm}$ $(\mathrm{n}=13) ; \mathrm{d}-1.20-1.35 \mathrm{~mm}$, mean $1.26 \mathrm{~mm}(\mathrm{n}=$ $13) ; \mathrm{h} / \mathrm{d}-1.45(\mathrm{n}=13)$.

Operculum: chestnut-coloured (Figs 6-8; FALNIOWSKI et al. 2012: 25, fig. 3 G19).

Ratio of males to females: $1: 3(n=4)$.

Animal (Figs 9-16): Except for the white mantle skirt, mantle, head and body wall pigmented black.
Ten ctenidium filaments $\left(\mathrm{n}=1 \delta^{\lambda}\right)$; inside the mantle cavity the intestine runs to the anus only slightly curved. Except for a black spot, the penis is pigmentless; it can be simple (FALNIOWSKI et al. 2012: 30, fig. 8 G19) or provided with a bifurcated outgrowth (Figs 9-16; $\mathrm{n}=1$ ). The renal oviduct carries a proximal and distal receptaculum (RS1, RS2) plus bursa. The tube-like bursa is of such a length that its top extends clearly beyond the turn of the intestine in front of the stomach $(n=2)$. 


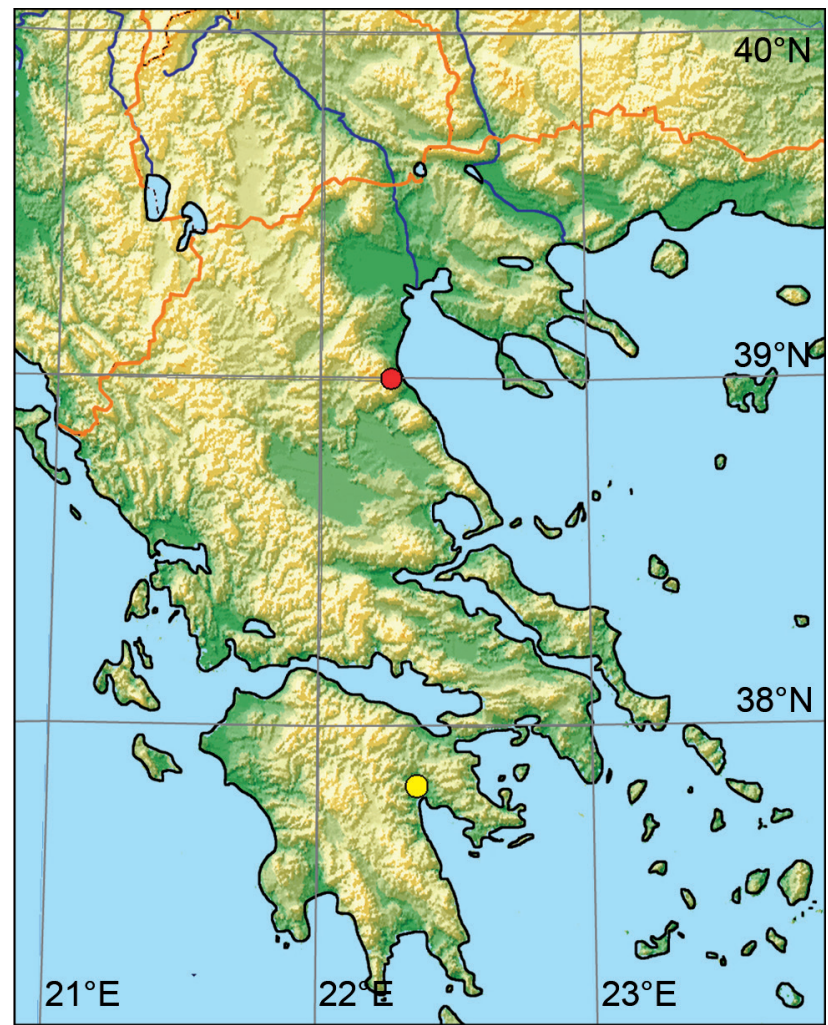

Fig. 17. Map with marked type localities. Yellow dot: Radomaniola tritonum $\left(37^{\circ} 33^{\prime} 07^{\prime \prime} \mathrm{N}, 22^{\circ} 43^{\prime} 03^{\prime \prime} \mathrm{E}\right)$; red dot: Grossuana tembii n. sp. (3958'26"N, 22³8'17"E)

Molecular data: see FALNIOWSKI et al. (2012: 33, fig. 14 G19).

Habitat and distribution: Known from the type locality only, a spring in the Thembi [Tembi] valley ca. $25 \mathrm{~km}$ north of Larisa in Thessalia (Figs 17-19).

\section{DISCUSSION}

\section{MALE AND FEMALE GENITALIA}

FALNIOWSKI et al. (2012) studied the type species of Radomaniola and of Grossuana, R. curta and G. serbica, and also R. tritonum and G. tembii n. sp. (as G. hohenackeri sensu FALNIOWSKI et al. 2012) from their type localities (FALNIOWSKI et al. 2012: 22, table 1; M9, M3, G5 and G19).

FALNIOWSKI et al. (2012: 25-26) state that as "a general rule, the variability of the penis was continuous. There was not a discrete difference between either Radomaniola and Grossuana and the nominal species/subspecies studied". Our results show that within the population of $G$. tembii n. sp. at its type locality, the bifurcated outgrowth may be present or missing.
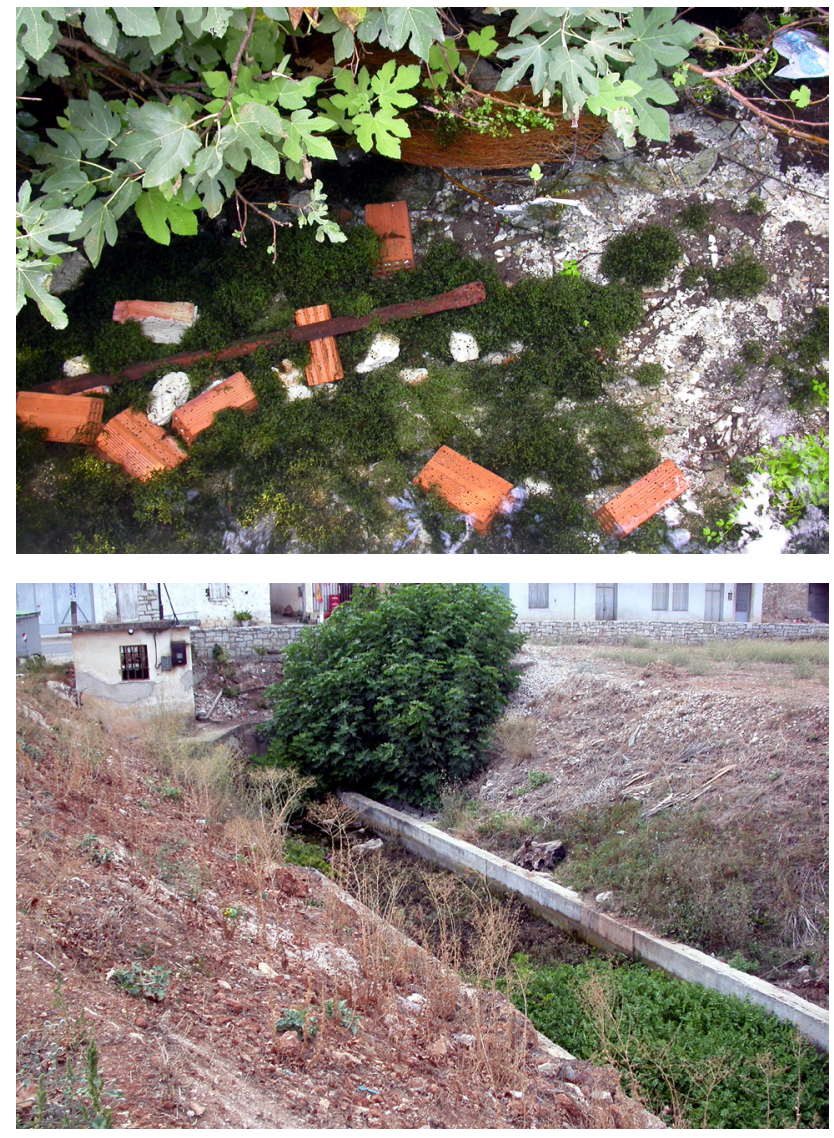

Figs 18-19. Greece, Thembi [Tembi] Valley, Spring of Athena, type locality of Radomaniola tembii n. sp.

Delimiting characters: In G. tembii n. sp. the parietal border of the aperture is somewhat more inclined and makes the aperture slightly smaller than in $R$. tritonum; see Figs 1-5 versus Figs 6-8. In a Bayesian tree based on COI sequences, both species are represented as belonging to different groups (FALNIOWSKI et al. 2012: 33, fig. 14 G19 and G5).

As regards the renal oviduct of the species of Radomaniola and of Grossuana, FALNIOWSKI et al. (2012: 30) found that "as in the case of the penis, there is a continuous variation in the shape and size of the bursa copulatrix as well as in the shape and size proportions of the receptacles".

We found that the bursa copulatrix of G. tembii n. sp. corresponded to the large tube-like bursa as described by RADOMAN (1983: 56, fig. 24) for G. serbica, the type species of the genus.

\section{PALUDINA HOHENACKERI KÜSTER, 1853}

KÜSTER (1853) obtained the material for his description from Charpentier. One of the labels in CHARPENTIER's collection reads: "208 [in red] 
Hohenackeri CHARP. Paludina brevis ["brevis" crossed out] Hohenaceri Graecia 1848".

Perhaps, Charpentier forwarded shells to Küster as Paludina brevis, and crossed brevis out upon KÜSTER's (1853) description as Paludina hohenackeri. Both Charpentier and Küster overlooked that Bourguignat had already described his Hydrobia tritonum from Lerna in 1852, one year previously. Bourguignat's material was collected by Saulcy "in intinere per Orientem annis 1850 et 1851". Charpentier must have obtained syntypes of Bourguignat's $H$. tritonum later. They are deposited in Charpentier's collection under no. 63. Because of the date "1848" on Charpentier's label for $P$. hohenackeri, it is unlikely that the material for Küster's Paludina hohenackeri was also collected by Saulcy.

On the other hand, it should not be excluded that Charpentier obtained his material of Küster's Paludina hohenackeri from Hohenacker, a Swiss like Charpentier. Hohenacker traded in herbarium material, possibly also shells. He had never been in Greece, but got material from Theodor von Heldreich who at that time lived in Athens (WÖRZ in litt. 05.12.2016 and 17.07.2017). From 1829 to 1842 Hohenacker was associated with the Esslinger Reiseverein [travelling union], Unio Itineraria.

\section{RADOMANIOLA FEHERI GEORGIEV, 2013}

The taxon was described after FALNIOWSKI's et al. (2012) investigations of the Radomaniola/Grossuana group in the Balkans. The type locality lies in the Taigetos Mts on the southern Peloponnese in Greece. The shell resembles that of the sample collected in the same mountain area and treated by FALNIOWSKI et al. (2012: 24, fig. 2 G3) as R. seminula (Frauenfeld, 1863).

\section{ACKNOWLEDGEMENTS}

We are grateful to ARNO WÖRZ (Stuttgart) for the information on Hohenacker and to PETE KOHNERT (München) and MICHAEL SCHRÖDL (München) for the photographs of syntypes of Hydrobia tritonum. We thank PETER REISCHÜTZ and ALEXANDER REISCHÜTZ (Horn) for the shells of $R$. tritonum, ANNE FREITAG (Lausanne) for the loan of Küster's original material of Paludina hohenackeri, and EMMANUEL TARDY (Genève) for the loan of syntypes of Hydrobia tritonum.

\section{REFERENCES}

BOETERS H. D. 1999. Präparation von Kleinprosobranchiern. Heldia 2 Sonderheft 3: 9-15.

Boeters H. D., GlÖER P., StAmenKović V. S. 2017. Thoughts about the Radomaniola/Grossuana group of the Balkan and Greece with the description of a new Grossuana species and of a neotype of Paludina hohenackeri Küster, 1853 (Caenogastropoda: Truncatelloidea: Hydrobiidae). Arch. Molluskenkd. 146: 187-202. https://doi.org/10.1127/arch.moll/146/187-202

Bourguignat J. R. 1852. Testacea novissima quae Cl. de Saulcy in itenere per Orientem annis 1850 et 1851, collegit. J.-B. Baillière, Lutetiae.

Bourguignat J. R. 1853. Catalogue raisonné des mollusques terrestres et fluviatiles recueillis par M. F. de Saulcy pendant son voyage en Orient. Gide \& Baudry, Paris. https://doi.org/10.5962/bhl.title.10475

CHARPEnTIER J. De 1855. Inventaire de la Collection des Mollusques d'eau douce de M. Jean de Charpentier. Unpublished at Musée de Zoologie de Lausanne, Lausanne.

FALNIOWSKI A., GeORgIEV D., OsIKOWSKI A., HOFMAN M. 2016. Radiation of Grossuana Radoman, 1973 (Caenogastropoda: Truncatelloidea) in the Balkans. J. Mollus. Stud. 82: 305-313. https://doi.org/10.1093/ mollus/eyv062

FALNIOWSKI A., SZAROWSKA M., GlÖER P., PeŠIĆ V. 2012. Molecules vs. morphology in the taxonomy of the

Radomaniola/Grossuana group of Balkan Rissooidea (Mollusca, Caenogastropoda). J. Conchol. 41: 19-36.

GEORGIEV D. 2013. A new species of Radomaniola Szarowska, 2006 (Gastropoda: Hydrobiidae) from Peloponnese, Greece. Acta Zool. Bulg. 65: 293-295.

GITTENBERGER E., BACKHUYS W., RIPKEN TH. E. J. 1970. De Landslakken van Nederland. Koninklijke Nederlandse Natuurhistorische Vereniging, Amsterdam.

KÜSTER H. C. 1852-1853. Die Gattungen Paludina, Hydrocaena und Valvata. In Abbildungen nach der Natur mit Beschreibungen. In: MARTINI F. H., CHEMNITZ J. H. (eds). Systematisches Conchylien-Cabinet, Band 1, Abtheilung 21 (1852) (1): 1-24, pls 1-2; (2): 25-56, pls 3-8; (1853) (3): 57-96, pls 9-14. Bauer \& Raspe, Nürnberg.

RADOMAN P. 1983. Hydrobioidea a superfamily of Prosobranchia (Gastropoda). I. Systematics. Serbian Academy of Sciences and Arts, Monographs 547, Department of Sciences 57: 1-256.

SCHÜTT H. 1980. Zur Kenntnis griechischer Hydrobiiden. Arch. Molluskenkd. 110 [1979]: 115-149.

\section{Received: March 23rd/April 11th, 2018 Revised: April 29th, 2018 Accepted: May 11th, 2018 Published on-line: June 5th, 2018}

